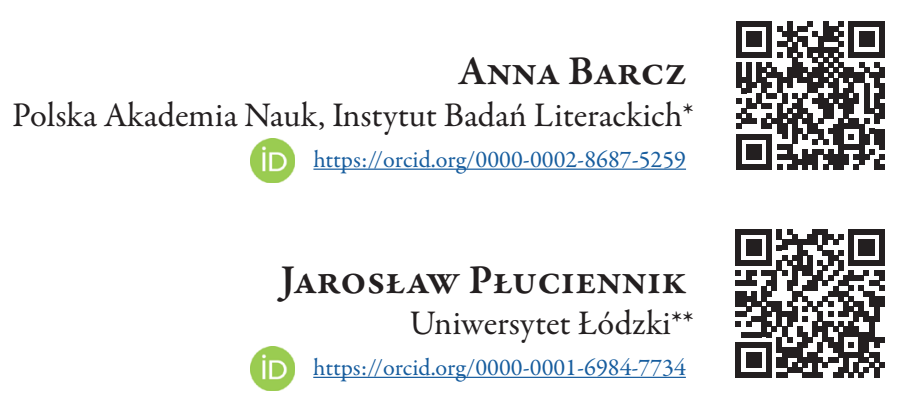

\title{
Post-pandemic Nature, Crisis, Catastrophes and Their Metaphorical Discourses. Editorial Introduction
}

\begin{abstract}
This article provides an extensive theoretical introduction to the main topic of the special issue of the journal. The authors aim at updating the metaphoric discourse on the environmental crisis and climate change in the time recently challenged by the global COVID-19 pandemic. Therefore, concerning the central theme of the journal's issue, the authors review the "catastrophic criticism" developed in environmental humanities and ask how the perspective of depicting elemental nature has changed since modernity and its technological approach to the living world. Another question is what kind of metaphors are needed to reflect on the catastrophes and crises we face; and how the very concepts of crisis and catastrophe function as metaphors in the theories developed in response to the COVID-19 pandemic.

By reopening the question of agential nature distorted by crisis and catastrophe in a post-pandemic world, this article analyses the discursive and generic reappropriations of environmental risks, including the regional cultural background (e.g. the Chernobyl figure for CEE countries). An example which illustrates the irrelevance of nature theorized as a resource in modernity is taken from the canonical Question Concerning Technology by Martin Heidegger. It is followed up by critical Frankfurt School philosophers' perspectives and is detectable in such environmentally loaded literature of Olga Tokarczuk's. The authors' findings show in this article how the pandemic realm has immensely repositioned how we read the leading theoreticians of catastrophic discourse. The examples are, e.g. Albert Camus or Oswald Spengler, and what texts we find relevant in the political, economic and social contexts of the debate on the contemporaneity of crisis and catastrophe, e.g. Niall Ferguson, Slavoj Žižek, Steven Pinker. In conclusion, this article draws on reopening the question on the role and authority of science in mitigating the climate and ecological crisis since the recent pandemic is an integral part of it.
\end{abstract}


* Polska Akademia Nauk, Instytut Badań Literackich ul. Nowy Świat 72, 00-330 Warszawa

e-mail:anna.barcz@ibl.waw.pl

** Uniwersytet Łódzki, Wydzial Filologiczny, Instytut Kultury Współczesnej, Katedra Teorii Literatury ul. Pomorska 171/173,90-236 Łódź

e-mail: jaroslaw.pluciennik@uni.lodz.pl 
Since the construction of the atomic bomb and the accompanying development of nuclear power plants, the environmental risks we face involve a new spectrum of reflection on what our globalized and technological modernity has caused. This type of modernity, which is no longer progressive and unable to respond to the environmental and climate crisis, unleashed hyperobjects, whose impact on people and the natural environment exceeds human scales of time and space (on this concept, see Morton 2013 ${ }^{1}$ ) and triggered what is called the Great Acceleration (McNeill and Engelke 2014) of the catastrophe of the world we know. As the Chernobyl example has shown, human and ecological disasters are dramatically converged and it is impossible to abstract from thinking about the environmental risk in everyday experience (Barcz 2020). In other words, for as long as this modernity lasts, we have been dealing with the risk of a total catastrophe transgressing global and local, public and private, culture and nature, but what we missed is how to limit the human agential role as the main cause of it (figured now by the Anthropocene - on this concept, see Garrard, Handwerk and Wilke 2014).

Such two-sidedness of catastrophe - which has always been about us and the real other(ness) - has been addressed by critical humanities in the theoretical, and poetical, language, for example, of rhizomatic connections and fluid relations with the living world. "Rhizomatic" in the sense of decentralizing human and rediscovering roots with other animals and biological world because of ethical concerns (see for example the rhizomatic perspective in ecocriticism discussed by Oppermann 2010); "fluid" in the sense of dismantling human exceptionality and fixed immaterial identities to demonstrate the causal (and harmful!) interrelatedness of human bodies with the world (see for example Thinking with $\mathrm{Wa}$ ter 2013). However, in the face of real, historically derived and scientifically predicted ends, the language of relationality can be disappointing and inadequate - perhaps, the most adequate now seems to be the one offered by extinction studies which tends to navigate its way through the catastrophic discourse of humanities (see Extinction Studies 2017). This, in turn, leads to some new aesthetic reappropriations of the sublime in the context of nuclear threat (Ferguson 1984; Hundorova 2017).

1 Perhaps even, Morton's theory of hyperobjects derives from such testimony, from Chernobyl catastrophism and literature (Barcz 2020: 133-135). 
Via cultural and literary examples, this special issue of "The Problems of Literary Genres" demonstrates some alternatives and references to extinction studies. What has deeply permeated the reflection of our authors is the detail gone into looking for access to catastrophe and crisis on a microscale, especially in regards to the intimacy of poetic language and experience (Franczak, Herman and Koza). Intimacy with catastrophe does not mean here secrecy but totality of this experience, which is possible to be communicated: how language articulates this sublime and uncanny experience of always present ("latent") disaster (Franczak); how language adapts and repositions the meanings of maternity in the context of catastrophic overpopulation for new generations (Herman); and how material and molecular approaches to nature can be part of a non-apocalyptic mode of living with catastrophe (Koza). To what extent the historical reconstructions of catastrophism in Judaism (Zurek) and a particular situation for Polish culture and politics at the turn of $18^{\text {th }} / 19^{\text {th }}$ centuries as in Woronicz's "visions of decline" (Ujma) translates into our real catastrophe's better understanding, we leave to the reader. Undoubtedly, though, all studies of catastrophism reproduce germs of resilience and adaptation to the most disturbing anxieties we still need to prepare ourselves for any eventuality. We also need to be alert to the manipulation of catastrophic imaginary, as the polar bear exemplifies in Piasecki's article, since the experience of reality of catastrophe that is happening now tends to be overshadowed by iconic/symbolic idolatry.

What is absent from the catastrophic criticism and environmental discourse of humanities is the cultural representation of agential role of real nature fighting back. Although the biosphere is more vulnerable than resilient to global warming and concrete species are direct victims of the human destructive activities towards environments, the global COVID-19 pandemic has shown how vulnerable human species are when hit by a microscopic organism. The virus's hyperobjective nature ${ }^{2}$ confirmed that there is no such project of modernity which could stop the catastrophe or make it reversible. This tiny monster of zoonotic origin disclosed the resilience of nature and rebelled against the overpopulated planet and globalized markets. Through vaccination, mostly prospective in the high-income countries (Mathieu, Ritchie, Ortiz-Ospina 2021), it was possible to put a hold on the human death toll but not the endangered and catastrophic situation of life of the planet ${ }^{3}$. In the end of the Anthropocene, nature threatens and takes revenge but it is not nature representing the environments we know (not "a parlour of trees" in the everglade, as in Antony Hegarty's song). This 'last' nature is hyperobjective, stamped by the approaching collapse.

The question is how the notion of nature's revenge can be operationalized and communicated? Has it a critical potential when ascribed to non-human actors representing nature and its hazardous phenomena? Does the concept of revenge as such, although being an anthropomorphic construct related to human emotions and affects, enable the translation within the catastrophic framework to include nature's response, nature as a subject of communication? And, is it possible to name such retaliation by the metaphoric 'revenge' to indicate the unstoppable processes of environmental commodification and degradation, imbalanced and dangerous atmospheric phenomena, to think otherwise about colonized, toxic and con-

2 Again, we are referring to Morton's concept and his update in the last book Hyposubjects (written with Dominic Boyer): "The book Hyperobjects is now in a way irrelevant - everyone knows, everyone intuitively feels (which is much more important) what a hyperobject is. Coronavirus is everywhere" (2021: 11).

3 The COVID global pandemic has caused a short-term drop in carbon emissions but will not stop climate change (UN News 2020). 
taminated environments which mutually colonize us? Framing these questions with nature's vengeance gives her power back and undermines the anthropocentric, Messianic belief in the rationally planned technological management of our rescue, even if projected in alliance with the non-human, post-AI, superintelligence that is just about to come (Lovelock 2019).

The elemental approach to empowered nature is a way of recognizing the reality of the end of the world. Some ecocritical studies exploring new modes of 'thinking with elements' (see for example, Material Ecocriticism 2014; Elemental Ecocriticism 2015) could be helpful in acknowledging the limits of thinking as regards to hazardous nature, and nature as the enemy of humans but not of the planet. Or, more reflection is needed on what does elemental nature mean today, when non-human actors, including hyperobjects, are beyond human control and the nature we know does not encompass the environmental reality that is at stake.

In the project of modernity such nature has been defined as a collection of resources, as matter devoid of agency: cultivated, set up and challenged to be defeated. As Martin Heidegger wrote in his Question Concerning Technology: "Air is now set upon to yield nitrogen, the earth to yield ore, ore to yield uranium, for example; uranium is set upon to yield atomic energy, which can be released either for destruction or for peaceful use" (1977: 15). In other words, nature within modernity means a mere resource for creating something else (for human flourishment); it means "an object" that does not rebel. This is also exemplified by Heidegger in this essay by the hydropower plant set into the current of the Rhine, which "is not built into the Rhine River as was the old wooden bridge that joined bank with bank for hundreds of years. Rather the river is dammed up into the power plant" (16). Is it still a river in the landscape? For Heidegger, it is a different form of revealing human instrumental relation to nature but for us today, more importantly, is that the river itself is in power to communicate beyond the dams and regulating barriers when it floods. The river is not muted, it is voiced by the ecological crisis.

The role of voicing 'subjective' nature was recognized by Frankfurt School philosophers as a cultural response to nature being 'repressed by human domination and objectification' (Donovan 2019: 5) in the period of modernity. At the same time, these ethically and politically engaged theoreticians, demonstrated what gaps, which arts, including literature, fills in. If 'the language of nature is mute, art seeks to make this muteness eloquent' (Adorno 1997: 78) and this perspective of putting nature in the centre of 'ecological' investigation provides the missing contexts of 'voicing' and 'muting' non-human agents through artistic means. Six years after the most catastrophic flood in our region, the Odra River flood in 1997, Olga Tokarczuk, who lived near this river in her childhood, wrote: 'The Odra had a set of moods - from the darkest green to charcoal black... She [the river] could be as strong as a pack animal that does not have a specific shape in itself but can become any creature she wishes' (2003: 154-155), and she added - the river is a 'living entity' (155). Outside of the human world, the Odra leads its own 'contemplative' life in the old riverbed, in its rich, swampy, insect-filled and human-unfriendly ecosystem (155). This 'poeticized' knowledge that the river serves the people while leading its own 'ecological' and non-human life that can become dangerous at will, should feed into the living cultural and literary memory.

The river in the context of rising flood risk is greatly and closely related to our Central Eastern European landscape example of how nature's revenge expresses itself within the catastrophic framework, since 'flooding has become more than a natural event, more than an occasional disaster: it has become a symptom of and synonymous with the global devastation 
that climate change is effecting' (Bracke and Ritson 2020: 1). As could be demonstrated in literary traditions and by taking a new approach to literary genres, such as flood narratives, beside the calmness of the river, the river's 'anger' is growing exponentially in our climateaffected era. However, anthropogenic climate change has led not only to flooding but also to the drying of rivers and challenged the possibilities of keeping biotic nature alive. In contrast to hyperobjective viruses, the rivers and all other environments we know are as vulnerable to the climate and environmental crisis as humans and other species, resulting in humanecological vulnerabilities that are entangled today more than ever. By asking this question of nature's taking revenge - and what kind of nature? - we want to add another dimension to this special issue on catastrophe and crisis in the environmental context, something that we would have never experienced without the pandemic realm. This problem is also a part of a special debate presented in this issue.

This debate reflects the current atmosphere of thought and culture during the criticism of the Anthropocene and the COVID-19 pandemic. Both multiplied the feeling of crisis and impending disasters. There is a growing awareness that science alone - whether data and epidemiological knowledge or knowledge about climate change - will not save humanity and individual communities. Therefore, it is necessary to pay attention not only to the experts' reflections in science, both in natural sciences and cognitive science, but also to listen to what theologians and ethicists have to say. By such a merging of perspectives, perhaps we will become prepared for the unexpected. We will return to this problem in a while.

During crises, very personalized cultural patterns of reactions return: for instance, more personal reports on social forums. In the past, these were journalistic, autobiographical reports. Today, similar problems occur in management sciences and economics. We are more and more aware of living with uncertainty, not only with risk but also with the general unknown. However, especially in our part of Central Eastern Europe, acute scepticism about climate change is one of the reasons why the former Soviet republics and countries of the former so called "Eastern bloc" might in their own way represent what Anthony Giddens, influenced by Ulrich Beck's 'risk society' studies (Heise 2008: 146), called 'risk culture' in a Western European context. These post-communist states are not only alienated from the dominant discourse on pollution and environmental damage, but also tend to establish their own nationalistic narrative regardless of scientific data - overcapitalization in the coal industry is just one of many examples, monumentalising Chernobyl - another one. As Ursula Heise noted, 'the study of risk perceptions and their sociocultural framing must form an integral part of an ecocritical understanding of culture' (2008: 13), but it must also problematize different cultural approaches to the human-environment relationship, especially in societies which are deeply affected by the past and which respond differently to crisis and nature's unpredictability.

Informed by our region's environmental culture, we may want to perceive differently what the catastrophe of the modernist project has uncovered and what relates to a criticism of human exceptionalism in many westernized economies in the time of pandemics. Theologians have had to deal with crises a long time ago and the answers to these crises have always been based on the attitudes of human humility towards the "extra-human". This attitude prompts us to consider religious and non-religious interpretations, which in the face of catastrophes make us use arrogant, colonizing and imperious attitudes. Crises and catastrophes teach us, also in the products of culture, humility and sensitivity, to live in uncertainty - and even, as in Albert Camus' "Pestilence" and his philosophical essays, with a sense of meaninglessness 
(sometimes it might be called even absurdity as in Camus, 1991). However, we must also not forget that we live in a more than human world and that in the face of crises and catastrophes, there is also human responsibility for others, solidarity or care (Weintrobe 2021, cf. Cohen, 2021). Hence the invocation in our invited debate of Karol Barth on the one hand and Søren Kierkegaard, on the other.

It is also worth paying attention to the different mental metaphors in two terms that we often use interchangeably: catastrophe and crisis. It is worth remembering these concepts and their metaphorical references, similarly, about the fact that we owe the concept of crisis to ancient medicine and the concept of a catastrophe to a broadly understood theory of literature and culture. Both concepts have a lot in common with literary and generic expectations, including the semantic ones.

Crisis (n.) in the literary sense refers to "that point in a story or play at which the tension reaches a maximum and a resolution is imminent. There may, of course, be several crises, each preceding a climax" (Cuddon 1991: 2007). The etymology indicates that crisis, is a "decisive point in the progress of a disease," also "vitally important or decisive state of things, point at which change must come, for better or worse," comes from the Latinized form of the Greek krisis "turning point in a disease, that change which indicates recovery or death." It is also crucial here that literally krisis meant also judgment, result of a trial, selection (from Greek "krinein" to separate, decide, judge).

It is worth remembering the relationship between a medical crisis understood in this way and hope or despair - in this mental model, is pointing out that from a tipping point, the path of events may deteriorate or improve, the mood curve may go up or down. Crisis as a critical or turning - point requires mindfulness, reflection and environmental knowledge. In this way, the current crises and catastrophes establish linguistic, metaphorical contact with the perennial problems of literary theory (once encompassing all spectacles), sometimes called theory and criticism, or critical theory or critical studies. It is important even more if the second metaphor commonly used in today's discourses is a metaphor derived from reflection on narration, a narratological metaphor: the word "catastrophe" means "overturning", "reversal of what is expected" (especially a fatal turning point in a drama, the winding up of the plot), from Latin catastropha, from Greek kadrophe.

The relationship between what happens in crisis and catastrophe is unexpected by definition, primarily structurally. Due to the presence of this structure, the unexpected "is becoming" expected. At this point, one can also recall a new metaphorical lexicon on the basis of catastrophic reflection. Niall Ferguson, a famous historian with a vision and great narrative, who is not only an academician, but also a political advisor and one of the most influential intellectuals in the world, wrote a book on that. Known for a book on Western Civilization (Civilization. The West and the Rest 2011), he also dealt with networks (The Square and the Tower - Networks, Hierarchies and the Struggle for Global Power, Penguin Book, 2017) and conspiracy theories. One can understand why there is a return to grand narratives in his writings. This year, during the pandemic which has not yet ended, he published Doom: The Politics of Catastrophe (2021). It is in this somewhat rushed piece of work that we find the sentence that "the history of humanity's changing susceptibility to infectious diseases is usually written as the history of pathogens - as one cursed microbe after another ... [But] telling the story may make as much sense as the story of ours developing social networks." Ferguson 
thus reverses the figurative perception of a catastrophic threat: it is not biological, natural pathogens that organize history, but social networks that must be seen as a kind of technology, like city, state, or civilization and democracy.

At this point, Ferguson puts in the Doom the metaphorization of the catastrophe in order, nowadays there is not only a crisis and a catastrophe, but such terms as "black swan," "grey rhinos" or "dragon kings." "Black swan" is a term used by Nassim Taleb (2008) to describe highly improbable events based on our knowledge. The "grey rhinos" is a metaphor for threats that we can see and recognize, but do nothing, look away, although it is in our interest to run away before it attacks. The rhinoceros can rummage in the ground, snort and prepare to charge, and we do nothing (the grey rhino is, for example, a mild seizure of power by authoritarian forces, such as Hitler's in 1933). “The Dragon King” is a double metaphor for an event that is either unusually large in size or influence (like "King") and has a unique origin (like "Dragon"). The danger is generated by a positive feedback, critical points (e.g. in case of a catastrophe of a nuclear power plant, see Sornette 2009).

If you know Ferguson's conservative views, it is not surprising that there is no reference to yet another instrumental metaphor: Naomi Klein's "shock doctrine." This metaphor is being discussed by another very topical commentator on the crisis and catastrophe of the pandemic. Slavoj Zižek finished writing the book when the pandemic was actually just announced at the end of March 2020 (see Žižek 2020; Craig 2020). You can see that many old thoughts have been reconfigured by the author and incorporated into new pandemic contexts. The author himself has repeatedly indicated that he learns the most from his opponents, the conservatives, which is why he starts perversely with reference to Christianity in the introduction entitled "Noli me tangere" [Latin for "Do not hold on to me" from John 20:17]. His interpretation of the symbolic presence of Christ in love between people sounds interesting in relation to the situation in a pandemic when social distancing from one another is obligatory. Real closeness and love must be replaced by symbolic closeness and love. Already in 2010, in the apocalyptic book Living in the End Times (2011), it not only makes a symbolic reference to the Four Horsemen of the Apocalypse, but also elevates its left-wing mission by referring to the Letter to the Ephesians of St. Paul (Ephesians 6:12). There he writes: "This book is therefore a book of struggle," in line with the amazingly accurate definition of Paul: "For we fight not with blood and flesh, but with heavenly powers, with principalities, with the rulers [cosmocrats] of this world of darkness, with evil spirits in heavenly circles." Or as you translate into today's language: "Our fight is not against genuinely corrupt individuals, but against the rulers simply, against their authority, against the global order and the ideological hoax that sustains it."

An interesting philosophical proposition is to look at epidemiology as a pattern for the proliferation of cultural representations (like those of Richard Dawkins and Dan Sperber, both use epidemiology as a cultural design for reflection on culture), and, for example, to look again at the philosophy of Leo Tolstoy, for whom the word infection was very important, or to be reminded of the Hegelian human spirit as a virus because the human psyche is a metaphorical virus that uses language (85-86).

Against the background of Naomi Klein's shock doctrine, Žižek's proposal is more unambiguous, Žižek calls it also metaphorically: disaster capitalism (97). We can agree with the final thesis that today's right question is what order will emerge from this deconstruction that is evident in the unintentional workings of the coronavirus (138). Žižek wishes to help with 
the system's self-awareness: he cites Bruno Latour, who rightly emphasized that the coronavirus crisis is a dressage rehearsal for the coming climate change. This shift is another crisis in which the reorientation of living conditions will be presented as a challenge to all of us, just as the details of everyday life we will have to learn to deal with carefully (122-123). Žižek proposes that science should become the basis of our (post) crisis actions, which he clearly addresses: "We are now compelled to admit that modern science, for all its hidden bias, is the dominant form of transcultural universalism. The epidemic is a welcome opportunity for science to reassert itself in this role" (136). Similarly, Greta Thunberg was right in saying that politicians should listen to science ${ }^{4}$. Žižek criticizes philosophers who would rather trust their gut feelings. In a situation where populists use the crisis to tighten the rings of authoritarianism and control (he recalls Wiktor Orban, who passed a law allowing him to rule by decrees for an unlimited time, p. 134), Žižek suggests using the shock to increase awareness of the fall and, as you can read in his 2010 book, the apocalypse. Here he creatively cites Ryszard Kapuściński and his "Shahinshah," a reportage that deals with the revolution in Iran. It is about the phenomenon of the fall of the regime - this one behaves like a cat hanging over the abyss, he will not fall until he looks down, when he looks, then it is already over (135).

According to Žižek in the "Four Horsemen of the Apocalypse" (2020) the ecological crisis is consequence of the biogenetic revolution, an imbalance in the system itself (problems with intellectual property; impending struggles for raw materials, food and water) and rapid social development, divisions and exclusions. The main conclusion of Žižek can be formulated in such a way that thanks to the pandemic, we can think about an alternative society and alternative modes of life. In this context, literary and metaphorical discourses seem very important; they were always present in catastrophe, especially in the 20th century.

The philosophy of the collapse of civilization was accompanied by catastrophic tendencies, which were expressed predominantly in the historiosophy of Oswald Spengler and by J. Ortega y Gasset, which proclaimed the decline of Western culture, or A. Toynbee, as well as in the philosophy of life and philosophical concepts of irrationalism; in European literature there were, inter alia, in the works of H. G. Wells, A. Huxley, F. Kafka, K. Čapek. Against this background, it is worth recalling Spengler's „The Decline of the West” from 1918. Spengler's vision of the rebellion of Western civilization against nature was most clearly presented in his treatise Man and Technics (2005, German original published in 1931), showing man from the naturalistic perspective as a natural being brought to life and caused by the laws of nature. In it, he presents the doctrine of human exceptionalism but formulates it differently from Heideggerian Question Concerning Technology, since he understands technology as a biological life tactic that is different among the plant world, different among herbivores, and the highest among predators, at the top of which is a man as a predator treating the whole world as his prey.

A unique position was held among those West European people who created higher cultures and were born, developing and dying in the natural rhythm of birth, experiencing a flourishing life and then death, as representatives of Faustian culture. They created a machine technique that became the most effective tool of human rebellion against a nature violated, manipulated, robbed of its strength, treated as prey by a predator. Nature, however,

4 On apocalyptic discourse in her writings and speeches, see Hintz, Płuciennik 2020. 
as the pandemic reveals itself, is stronger and this rebellion must end in a catastrophe and the collapse of the Faustian culture of the West, a catastrophe in convulsions of internal conflicts between the masses and elites, and a loss of effectiveness.

It seems that today such an unequivocally pessimistic view of civilization is untenable, especially in the context of the writings of Steven Pinker, who argues especially in his Enlightenment now (Pinker 2018), interdisciplinary and empirically that the development of civilization eliminates evil in the human world. The Achilles' heel in his considerations is precisely this humanistic point of view: from the human point of view, the development of civilization is not just the advancement of medicine and the extension of human life, but also an invention of concepts of human rights and emancipation. We must not forget that technology is not only coal that accelerates modernity, but also nuclear and hydrogen energy. It might create some optimism, however we may differ in the attitudes towards that. Going back to the Enlightenment with Pinker we might want to ask: what kind of Enlightenment do we need now if we obviously need enlightened science and humanism. On the other hand, it is precisely this perspective of modernity that does not consider the reflection that was also present in the $20^{\text {th }}$ century, such as Albert Schweitzer. His Reverence for life, of a somewhat forgotten thinker, theologian, philosopher, activist, doctor, music historian and musician, makes us look at the history of civilization from the point of view of the "hippopotamus," or endangered "octopuses" or "elephant queens." We can recall his "reverence for life" when we read that, according to the psychologists of the current catastrophe, we lacked care: human responsibility for others, solidarity or just care (Weintrobe 2021, cf. Cohen 2021).

By inviting you to read our monographic issue, we encourage you to be critical as well as suspicious because this is what the crisis itself facilitates: you may want to open up to the unexpected, make yourself be aware of many sides of the catastrophic scenarios. The genres and types of cultural discourse with their metaphorization can help us use culture as an adaptive tool. Both our authors of the articles, and the participants of our editorial debate, either those representing science (Gärdenfors, Stern), the humanities (Melberg, Vermeulen, Jackelén, Hintz) or social sciences (Czapla, Marcinkowska) call for such attention in this unexpected world, a world not only of many risks but of general uncertainty.

We cordially invite you to read our special issue.

Anna Barcz and Jarostaw PŁuciennik 


\section{Bibliography}

Adorno Theodor (1997), Aesthetic Theory, ed. Adorno G., Tiedemann R., trans. R. Hullot-Kentor, University of Minnesota Press, Minneapolis.

Barcz Anna (2020), Environmental Cultures in Soviet East Europe: Literature, History and Memory, Bloomsbury Academic, London.

Bracke Astrid, Ritson Kate (2020), Water Rising, "Green Letters: Studies in Ecocriticism”, no. $1(24)$.

Camus Albert (1991), The Myth of Sisyphus and Other Essays, trans. J. O’Brien, Vintage Books, New York [Translation originally published by Alfred A. Knopf, 1955. Originally published in France as Le Mythe de Sisyphe by Librairie Gallimard 1942].

Coen Deborah R. (2021), Promoting a Culture of Climate Care, "Science", no. 372, issue 6543 (14 May), p. 693, doi: 10.1126/science.abi7088.

Craig David (2020), Pandemic and Its Metaphors: Sontag Revisited in the COVID-19 Era, "European Journal of Cultural Studies", vol. 23, issue 6 (7 July), p. 1025-1032, doi: $10.1177 / 1367549420938403$.

Donovan Josephine (2019), Ethical Mimesis and Emergence Aesthetics, "Humanities", no. 8(2), p. 102, doi: 10.3390/h8020102.

Elemental Ecocriticism: Thinking with Earth, Air, Water, and Fire (2015), ed. Cohen J.J., Duckert L., University of Minnesota Press, Minneapolis.

Extinction Studies: Stories of Time, Death, and Generations (2017), ed. Rose D.B., van Dooren T., Chrulew M., Columbia UP, New York.

Ferguson Frances (1984), The Nuclear Sublime, "Diacritics", vol. 14, no. 2, p. 4-10, doi: $10.2307 / 464754$.

Garrard Greg, Handwerk Gary, Wilke Sabine (2014), Imagening Anew: Challenges of Representing the Anthropocene, "Environmental Humanities", no. 5.

Heidegger Martin (1977), The Question Concerning Technology [in:] The Question Concerning Technology and Other Essays, transl. W. Lovitt, Garland Publishing, New York-London.

Heise Ursula K. (2008), Sense of Place and Sense of Planet. The Environmental Imagination of the Global, Oxford UP, New York.

Hintz Marcin, Płuciennik Jarosław (2020), Patterns of Protestant Ethics and Modern Culture in Greta Thunberg's Public Appearances, "Journal for the Study of Religions and Ideologies", vol. 19 , no. 57 , p. $63-80$.

Hundorova Tamara (2017), Gatunek czarnobylski: wyparcie realnego i nuklearna sublimacja, trans. P. Tomanek [in:] Po Czarnobylu. Miejsce katastrofy $w$ dyskursie wspótczesnej humanistyki, ed. Boruszkowska I., Glinianowicz K., Grzemska A., Krupa P., Wyd. UJ, Kraków, p. 55-66.

Lovelock James (2019), Novacene: The Coming Age of Hyperintelligence, The MIT Press, Cambridge (MA).

Material Ecocriticism (2014), ed. Iovino S., Oppermann S., Indiana University, Bloomington.

Mathieu Edouard, Ritchie Hannah, Ortiz-Ospina Eesteban et al. (2021), A Global Database of COVID-19 Vaccinations, "Nature Human Behaviour", www.nature.com/articles/s41562021-01122-8 [access: 19.06.2021].

McNeill John Robert, Engelke Peter (2014), The Great Acceleration: An Environmental History of the Anthropocene since 1945, The Belknap Press of Harvard UP, Cambridge MA. 
Morton Timothy (2013), Hyperobjects. Philosophy and Ecology after the End of the World, University of Minnesota Press, Minneapolis.

Morton Timothy, Boyer Dominic (2021), Hyposubjects. On Becoming Human, Open Humanities Press, London.

Oppermann Serpil (2010), The Rhizomatic Trajectory of Ecocriticism, "Ecozon@: European Journal of Literature, Culture and Environment", vol. 1, no. 1.

Pinker Steven (2018), Enlightenment Now: The Case for Reason, Science, Humanism, and Progress, Viking, an imprint of Penguin Random House LLC, New York.

Sornette Didier (2009), Dragon-Kings, Black Swans and the Prediction of Crises, "International Journal of Terraspace Science and Engineering”, no. 2(1), p. 1-18 [arxiv.org/abs/0907.4290 and ssrn.com/abstract $=1470006]$.

Spengler Oswald (2015), Man and Technics: A Contribution to a Philosophy of Life, Second edition, Arktos, London.

Taleb Nassim Nicholas (2008), The Black Swan: The Impact of the Highly Improbable, Penguin, London.

Thinking with Water (2013), ed. Chen C., MacLeod J., Neimanis A., McGill-Queen's UP, Montreal.

Tokarczuk Olga (2003), Odra [in:] Moment niedżwiedzia, Krytyka Polityczna, Warszawa.

UN News (2020), news.un.org/en/story/2020/04/1062332 [access: 19.06.2021].

Weintrobe Sally (2021), Psychological Roots of the Climate Crisis: Neoliberal Exceptionalism and the Culture of Uncare, Bloomsbury Academic, New York-London.

Žižek Slavoj (2011), Living in the End Times, Verso, London-New York.

Žižek Slavoj (2020), Pandemic: COVID-19 Shakes the World, Polity Press, New York. 